\title{
Neurobiology of Gambling Behaviors
}

\author{
Marc N. Potenza \\ Departments of Psychiatry, Neurobiology, and Child Study Center, Yale University School of \\ Medicine, New Haven, Connecticut
}

\begin{abstract}
For many, gambling is a recreational activity that is performed periodically without ill effects, but for some, gambling may interfere with life functioning. A diagnostic entity, pathological gambling, is currently used to define a condition marked by excessive and problematic gambling. In this review, the current status of understanding of the neurobiologies of gambling and pathological gambling is described. Multiple neurotransmitter systems (norepinephrine, serotonin, dopamine, opioid and glutamate) and brain regions (ventral striatum, ventromedial prefrontal cortex, insula, among others) have been implicated in gambling and pathological gambling. Considerations for future directions in gambling research, with a view towards translating neurobiological advances into more effective prevention and treatment strategies, are discussed.
\end{abstract}

\section{Keywords}

Gambling; neuroimaging; neurobiology; treatment development

\section{Introduction}

\section{Anticipated Changes in Gambling Disorder Nomenclature, Definition, and Classification}

Gambling, defined as placing something of value at risk in the hopes of gaining something of greater value, is a widely prevalent behavior that has been popular for millennia. While most people gamble without problems, a sizable minority (up to about 5\%) develops gambling-related problems. Those with more severe gambling problems may meet criteria for pathological gambling (PG), a diagnostic entity introduced in the Diagnostic and Statistical Manual (DSM) in 1980 [1]. In anticipation of the forthcoming editions of the DSM (DSM-5), several changes to PG have been proposed. First, the name of the condition is being proposed to change to "Gambling Disorder", as some have found the term pathological stigmatizing. Second, the threshold for diagnosing a case is proposed to shift from 5 of 10 inclusionary criteria to 4 of 9 , with the "commission of gambling-related illegal

\footnotetext{
Correspondence concerning this article should be addressed to Marc N. Potenza, MD, PhD, Yale University School of Medicine, CMHC, 34 Park Street, New Haven, CT, 06519, USA. marc.potenza@yale.edu. .

Disclosures: The authors report that they have no financial conflicts of interest with respect to the content of this manuscript. Dr. Potenza has received financial support or compensation for the following: Dr. Potenza has consulted for and advised Boehringer Ingelheim; has consulted for and has financial interests in Somaxon; has received research support from the National Institutes of Health, Veteran's Administration, Mohegan Sun Casino, the National Center for Responsible Gaming and its affiliated Institute for Research on Gambling Disorders, and Forest Laboratories, Ortho-McNeil, Oy-Control/Biotie, Psyadon and Glaxo-SmithKline pharmaceuticals; has participated in surveys, mailings or telephone consultations related to drug addiction, impulse control disorders or other health topics; has consulted for law offices and the federal public defender's office in issues related to impulse control disorders; provides clinical care in the Connecticut Department of Mental Health and Addiction Services Problem Gambling Services Program; has performed grant reviews for the National Institutes of Health and other agencies; has guest-edited journal sections; has given academic lectures in grand rounds, CME events and other clinical or scientific venues; and has generated books or book chapters for publishers of mental health texts.
} 
acts" criterion removed. For comparison, a diagnosis of a substance-use disorder in DSM-5 may require meeting 2 or more inclusionary criteria. Third, PG is being proposed for reclassification into the category of "Addictions and Related Disorders", a move from its current location currently in "Impulse Control Disorders Not Elsewhere Classified" [2]. This proposed reclassification is based on data from epidemiological, clinical and neurobiological domains $[3,4]$. In that PG may be conceptualized as an addiction without the drug, investigations into its neurobiology have often been based on understandings of drug addictions and/or have contrasted PG with substance-use disorders [5, 6**].

Given the recently proposed changes to PG, this article will review the neurobiology of gambling and PG within the context of this changing landscape and will discuss future directions for research, with a view towards translating improved neurobiological understandings into better prevention and treatment strategies. Recent articles have reviewed in depth the neurobiology of PG and its relationship with the neurobiologies of substanceuse disorders and impulse-control disorders [ $\left.6^{* *}, 7^{* *}\right]$. Here, we will summarize main findings from neurochemical and neural research of PG and subsyndromal gambling, using the tables to provide detailed information, and consider future directions.

\section{Neurochemistry of Gambling and PG}

Multiple neurochemical systems have been implicated in gambling and PG (Table 1). Adrenergic systems have been hypothesized to contribute to arousal and excitement, serotonin to impulse control, dopamine to rewarding and reinforcing aspects, opioids to pleasure/urges, cortisol to stress responsiveness, and glutamate to cognitive functioning including cognitive flexibility. Data exist consistent with these proposed roles (see Table 1), although there appears to be a more complex relationship (e.g., drugs that act as D2-like dopamine receptor agonists and antagonists have both been linked to pro-gambling motivations and behaviors, suggesting that individual differences might be particularly important to consider [8]). Arguably the most empirically validated form of pharmacotherapy for PG involves opioid antagonists, although these appear efficacious for only a portion of individuals with PG and have not been examined for long-term efficacy [9**]. As such, there exists significant need for translating information about the neurobiological underpinnings of PG into treatment advances.

\section{Neural Biologies of Gambling and PG}

Multiple cognitive processes have been linked to propensities to gamble and to the severity of gambling problems (Table 2). Although individuals with PG often score within normal range on intelligence tests and may show fewer cognitive deficits as compared to individuals with substance addictions [10], they often score highly on measures of impulsiveness and low on measures of self-control [6]. Additional behavioral measures (e.g., assessing decision-making and reversal learning) may capture deficits in PG not apparent in standard assessments of intelligence (Table 2). Differences in brain function relating to multiple cognitive domains (cognitive control, decision-making, reward/loss and "near-miss" processing, delay and probabilistic discounting, reversal learning, alternation learning, and risk-taking) have all been linked to PG or problem-gambling severity. Much of this literature supports relatively diminished activation of the prefrontal cortex (particularly ventromedial but also ventrolateral and orbitofrontal) and subcortical regions (particularly the ventral striatum) (Table 2). However, reports of relatively increased activation exist, particularly in response to gambling cues, although the findings are not uniform across studies (Table 2). In addition to the regional brain activation findings tabulated, preliminary data have identified regions of poorer white matter integrity in PG, with poorer integrity linked to behavioral tendencies in PG (e.g., fun-seeking tendencies) [11, 12]. These findings suggest that brain circuits, particularly those involving ventral prefrontal, ventral striatal and limbic regions, 
may contribute importantly to reward-related decision-making that drive gambling behaviors and underlie PG.

\section{Important Next Steps: Translating Neurobiological Findings into Prevention and Treatment Advances}

The proposed change in threshold for making a diagnosis of a gambling disorder in DSM-5 raises questions about where to "draw the line" for making a diagnosis and whether clinically relevant levels of problem-gambling severity exist. Different thresholds have been proposed, ranging from non-gambling to PG (Figure 1) [13]. Different thresholds for defining groups based on problem-gambling severity have been identified using data-driven methodologies (e.g., latent class analysis [14]) or creation of groups based on numbers of inclusionary criteria for PG acknowledged (e.g., [15]), and data indicate that the different levels of problem-gambling severity shown in figure 1 have clinical relevance (e.g., with respect to non-gambling psychiatric conditions [16]). Data also indicate that people transition through different stages based on levels of problem-gambling severity [17], although the factors that promote transitions from lesser to greater levels of problemgambling severity or vice-versa are not well understood and represent an important and needed area of investigation.

Multiple factors likely influence these transitions. For example, women have been found to demonstrate faster transitions from gambling initiation to gambling problems (a process termed "telescoping" [18]), although the biological factors underlying the telescoping process (or sex differences in the neurobiology of PG) have yet to be examined systematically. Life experiences may also influence transitions in both detrimental and protective fashions. For example, resiliency factors may include being married, having strong social networks, being more educated, having larger incomes, participating in religious services utilizing protective cognitive and behavioral strategies [19]. On the other hand, risk factors may include trauma and stress (including early childhood adversity), early exposure to and initiation in gambling, truant or delinquent behaviors, impulsive tendencies, substance-use behaviors, and other psychiatric or medical conditions [19-21]. Importantly, these risk and protective factors may vary and operate biologically in developmentally sensitive fashions, making the consideration of people's developmental statuses important in understanding gambling transitions and trajectories [22**].

These factors may also interact in important manners. Commonly occurring allelic variants may demonstrate clinically relevant interactions with environmental factors to confer risk or protection in manners that could influence gambling transitions. For example, the gene coding for the serotonin transporter (SLC6A4) has commonly occurring short and long variations in the promoter region that lead to differential protein expression and are associated with different patterns of amygdala responsiveness and vulnerability to depression based on childhood maltreatment [23, 24]. The identification of specific epigenetic factors underlying such vulnerability and resilience and the extent to which such factors may influence gambling transitions and trajectories warrant direct investigation. In order to investigate such phenomena more precisely, a better understanding of the genetic underpinnings of gambling and PG is warranted. Although data suggest that 50\% or more of the variance for PG is related to genetic factors [25, 26], candidate gene analyses have generated mixed results and more systematic investigations (e.g., genome-wide analyses) have yet to be published [7**].

Multiple constructs (e.g., impulsivity or facets thereof) have been proposed as important intermediary phenotypes or potential endophenotypes for gambling and PG [6**]. Specific aspects of impulsivity (e.g., relating to rapid response and choice) may be dissociable, and within each domain, self-report and behavioral measures may relate differently to clinically 
relevant measures like treatment outcome [22**]. These constructs may also be sensitive to environmental factors (e.g., stress, reward), and thus contextual considerations warrant examination. Impulsivity-related constructs may be multi-faceted and associate in specific fashions with gambling transitions and trajectories at different developmental epochs [22]. As temperamental and related behavioral characteristics at early ages have been linked prospectively to multiple behaviors and phenomena (substance use, academic performance, and brain responses) [27], the extent to which such factors relate to gambling behaviors should be examined directly as such factors may influence prevention and policy efforts (e.g. targeting children with high impulsiveness).

An important line of research in addictions involves understanding the brain mechanisms underlying change during treatment, and behavioral and pharmacological interventions may have shared or distinct mechanisms of action [28**]. Integrating neuroimaging measures into randomized clinical trials offers the opportunity to understand the mechanisms underlying effective treatments and their active ingredients. Such data could provide a stronger foundation for modifying and adapting therapies or combinations thereof in order to improve their efficacies. While research in this area is further along in substance addictions than in PG, mechanisms for active ingredients of behavioral therapies for PG have been proposed, along with the hypothesized neural systems that may underlie their actions [29**]. Further research is needed to examine these hypotheses and to translate the findings into improved treatments.

\section{Future Directions}

As an increasingly large and diverse array of biotechnologies permit the acquisition of data from multiple domains, it is increasingly important to gather and synthesize information from multiple areas in order to understand gambling behaviors. Arguably, this work has progressed further in understanding non-gambling conditions (e.g., those relating to depression or substance-use disorders) than it has in understanding gambling behaviors. Important areas to consider include the integration of genetic and neuroimaging measures and the concurrent and integrative use of multiple imaging modalities (e.g., diffusion tensor imaging, high-resolution structural scanning, functional magnetic resonance imaging, and positron emission tomography). Critically important in this work is the inclusion of careful phenotypic assessments (diagnostic, behavioral, and self-report) that can be linked to imaging measures in order to understand how individual differences might relate to biological measures underlying gambling behaviors.

Advanced analytical techniques also deserve attention, particularly those that consider connectivity or identify brain circuitry. Independent component analysis has been used in preliminary examinations to identify functionally integrated activations (or brain circuits) that relate to cognitive control differently in cocaine-dependent and non-addicted comparison subjects; within the cocaine-dependent subjects, relationships with treatment retention and drug abstinence were also examined [30*]. The identification of circuitry relating specifically (and perhaps differentially) to pathology and treatment outcome should improve our understanding of treatment mechanisms and lead to better therapies.

Translational efforts involving animal models of gambling behaviors have only begun to be examined in gambling. Rat models examining near-miss and gambling task phenomena have been developed and used to examine neurochemical contributions to these processes [ 31 , 32]. Given advances in targeted gene expression in rodents [33], such techniques may help better understand how specific molecular entities within specific cells and neuronal circuits influence gambling behaviors. As animal research permits alternative and complementary avenues of investigation, it should help promote a better understanding of the pathophysiology of PG and identify novel targets for treatment development. 
Using neuroscience to influence policy remains a goal for gambling. While specific avenues of research have direct policy implications (e.g., findings linking lottery-ticket-gift receipt to problem-gambling behaviors and more permissive attitudes towards gambling [34]), investigations into the biological factors relating to PG and gambling transitions may hold implications as well. Important in this regard is understanding better the factors that relate gambling, particularly PG, to psychiatric, neurological and medical illnesses, in addition to the biological factors that may promote transitions to levels of greater/lesser problemgambling severity.

\section{Conclusions}

While the past decade has witnessed a significant advance in our understanding of the neurobiology of gambling and PG, there remain many poorly understood aspects. Important gaps exist with respect to integrating information from multiple domains and understanding how specific factors relate (perhaps in interactive fashions) to gambling transitions and trajectories across the lifespan. While empirically validated treatments for PG have varying degrees of support, little is known about their mechanisms of action or how specific therapies might work better for specific individuals. Generating improved prevention, treatment and policy efforts from a better understanding of the neurobiology of gambling and PG seems an attainable future goal.

\section{Acknowledgments}

This study was funded by National Institute on the Drug Abuse (NIDA) grant P20 DA027844, Connecticut Department of Mental Health and Addiction Services, Connecticut Mental Health Center, and the National Center for Responsible Gaming's Center of Excellence in Gambling Research at Yale University.

\section{References}

1. American Psychiatric Association. Diagnostic and Statistical Manual of Mental Disorders. 3rd ed. Washington, DC: 1980.

2. Holden C. Behavioral addictions debut in proposed DSM-V. Science. 2010; 327:935. [PubMed: 20167757]

3. Potenza MN. Should addictive disorders include non-substance-related conditions? Addiction. 2006; 101(Suppl 1):142-51. Epub 2006/08/26. [PubMed: 16930171]

4. Potenza MN, Koran LM, Pallanti S. The relationship between impulse control disorders and obsessive-compulsive disorder: A current understanding and future research directions. Psychiatry Res. 2009; 170:22-31. [PubMed: 19811840]

5. Potenza MN. The neurobiology of pathological gambling and drug addiction: an overview and new findings. Philos Trans R Soc Lond B Biol Sc. 2008; 363:3181-9. [PubMed: 18640909]

6 **. Leeman RF, Potenza MN. Similarities and Differences between Pathological Gambling and Substance Use Disorders: A Focus on Impulsivity and Compulsivity. Psychopharmacology (Berl). 2012; 219:469-90. [PubMed: 22057662] 6.** A recent, comprehensive review that covers neurobiological similarities and differences between pathological gambling and substance-use disorders, with a focus on the intermediary phenotypes of impulsivity and compulsivity.

7 **. Leeman RF, Potenza MN. A Targeted Review of the Neurobiology and Genetics of Behavioral Addictions: An Emerging Area of Research. Can J Psychiatry. in press. 7.** A recent, comprehensive review of the genetics and neurobiologies of pathological gambling and other "behavioral" addictions.

8. Delaney M, Leroi I, Simpson J, Overton PG. Impulse control disorders in Parkinson's disease: a psychosocial perspective. J Clin Psychol Med Settings. 2012; 19(3):338-46. [PubMed: 22581074]

$9 * *$. Bullock SA, Potenza MN. Pathological gambling: Neuropsychopharmacology and treatment. Curr Psychopharmacol. 2012; 1:67-85. 9.** A recent review that describes the 
neuropsychopharmacology and treatment (particularly pharmacological) of pathological gambling, with a proposed pharmacological treatment algorithm.

10. Lawrence AJ, Luty J, Bogdan NA, Sahakian BJ, Clark L. Problem gamblers share deficits in impulsive decision-making with alcohol dependent individuals. Addiction. 2009; 104:1006-15. [PubMed: 19466924]

11. Yip SW, Lacadie C, Xu J, Worhunsky PD, Fulbright RK, Constable RT, Potenza MN. Reduced genual corpus collosal white matter integrity in pathological gambling and its relationship to alcohol abuse or dependence. World J Biol Psychiatry. in press.

12. Joutsa J, Saunavaara J, Parkkola R, Niemela S, Kaasinen V. Extensive abnormality of brain white matter integrity in pathological gambling. Psychiatry Res. 2011; 194(3):340-6. http://dx.doi.org/ 10.1016/j.pscychresns.2011.08.001. Epub 2011/11/15. [PubMed: 22079653]

13. Shaffer HJ, Korn DA. Gambling and related mental disorders: A public health analysis. Annu Rev Public Health. 2002; 23:171-212. [PubMed: 11910060]

14. Xian H, Shah KR, Potenza MN, Volberg RA, Chantarujikapong S, True WR, lyons MJ, Tsuang MT, Eisen SA. A Latent Class Analysis of DSM-III-R Pathological Gambling Criteria in MiddleAged Men: Association with Psychiatric Disorders. J Addict Med. 2008; 2:85-95. [PubMed: 21768977]

15. Toce-Gerstein M, Gerstein DR, Volberg RA. A hierarchy of gambling disorders in the community. Addiction. 2003; 98:1661-72. [PubMed: 14651495]

16. Desai RA, Potenza MN. Gender differences in the associations between past-year gambling problems and psychiatric disorders. Soc Psychiatry Psychiatr Epidemiol. 2008; 43:173-83. [PubMed: 18080792]

17. Shaffer H, Hall MN. The natural history of gambling and drinking problems among casino employees. J Soc Psychol. 2002; 142:405-24. [PubMed: 12153120]

18. Potenza MN, Steinberg MA, McLaughlin S, Wu R, Rounsaville BJ, O’Malley S. Gender-related differences in the characteristics of problem gamblers using a gambling helpline. The Am J Psychiatry. 2001; 158:1500-5.

19. Tse S, Hong S-L, Wang C-W, Cunningham-Williams RM. Gambling Behavior and Problems Among Older Adults: A Systematic Review of Empirical Studies. J Gerontol B Psychol Sci Soc Sci. in press, http://dx.doi.org/10.1093/geronb/gbs068.

20. Petry NM, Steinberg KL. Childhood maltreatment in male and female treatment-seeking pathological gamblers. Psychol Addict Behav. 2005; 19(2):226-9. Epub 2005/07/14. [PubMed: 16011396]

21. Rahman AS, Pilver CE, Desai RA, Steinberg MA, Rugle L, Krishnan-Sarin S, Potenza MN. The relationship between age of gambling onset and adolescent problematic gambling severity. $\mathrm{J}$ Psychiatr Res. 2012; 46(5):675-83. Epub 2012/03/14. [PubMed: 22410208]

22 **. Potenza MN. Biological contributions to addictions in adolescents and adults: Prevention, treatment and policy implications. J Adolesc Health. 2013; 52(S2):S22-S32. [PubMed: 23535053] 22.** A perspective on translating biological contributions to addictions and addiction vulnerability into improved prevention, treatment and policy strategies.

23. Kaufman J, Yang BZ, Douglas-Palumberi H, Houshyar S, Lipschitz D, Krystal JH, Gelernter J. Social supports and serotonin transporter gene moderate depression in maltreated children. Proc Natl Acad Sci USA. 2004; 101:17316-21. [PubMed: 15563601]

24. Hariri AR, Mattay VS, Tessitore A, Kolachana B, Fera F, Goldman D, Egan MF, Weinberger DR. Serotonin transporter genetic variation and the response of the human amygdala. Science. 2002; 297(5580):400-3. [PubMed: 12130784]

25. Eisen SA, Lin N, Lyons MJ, Scherrer J, Griffith K, True WR, Goldberg J, Tsuang MT. Familial influences on gambling behavior: an analysis of 3359 twin pairs. Addiction. 1998; 93:1375-84. [PubMed: 9926543]

26. Slutske WS, Zhu G, Meier MH, Martin NG. Genetic and environmental influences on disordered gambling in men and women. Arch Gen Psychiatry. 2010; 67:624-30. [PubMed: 20530012]

27. Casey BJ, Somerville LH, Gotlib IH, Ayduk O, Franklin NT, Askren MK, Jonides J, Berman MG, Wilson NL, Teslovich T, et al. Behavioral and neural correlates of delay of gratification 40 years later. Proc Natl Acad Sci USA. in press, http://dx.doi.org/10.1073/pnas.1108561108. 
28 **. Potenza MN, Sofuoglu M, Carroll KM, Rounsaville BJ. Neuroscience of behavioral and pharmacological treatments for addictions. Neuron. 2011; 69:695-712. [PubMed: 21338880] 28.** A review describing how an emerging and improving neuroscientific understanding may promote the development of pharmacotherapies and behavioral therapies for addictions.

29 **. Potenza MN, Balodis IM, Franco CA, Bullock S, Xu J, Chung T, et al. Neurobiological considerations in understanding behavioral treatments for pathological gambling. Psychol Addict Behav. in press. 29.** A review and proof-of-concept demonstration highlighting how neuroimaging may improve behavioral therapy development for pathological gambling, with proposed active ingredients and hyptohesized neural contributions to behavioral therapies for pathological gambling.

30 *. Worhunsky PD, Stevens M, Carroll KM, Rounsaville BJ, Calhoun VD, Pearlson GD, Potenza MN. Functional Brain Networks Associated with Cognitive Control, Cocaine Dependence and Treatment Outcome. Psychol Addict Behav. in press. 30.* An original research manuscript demonstrating how independent component analysis can idenitfy brain circuits differentially related to diagnosis, retention and abstinence in cocaine dependence.

31. Winstanley CA, Cocker PJ, Rogers RD. Dopamine modulates reward expectancy during performance of a slot machine task in rats: evidence for a 'near-miss' effect. Neuropsychopharmacology. 2011; 36:913-25. [PubMed: 21209612]

32. Zeeb FD, Robbins TW, Winstanley CA. Serotonergic and dopaminergic modulation of gambling behavior as assessed using a novel rat gambling task. Neuropsychopharmacology. 2009; 34:2329_ 43. [PubMed: 19536111]

33. Zhao S, Ting JT, Attalah HE, Qiu L, Tan J, Gloss B, Augustine GJ, Deisseroth K, Luo M, Graybiel AM, Feng G. Cell-type Specific Optogenetic Mice for Dissecting Neural Circuitry Function. Nat Methods. 2011; 8(9):745-52. [PubMed: 21985008]

34. Kundu PV, Pilver CE, Desai RA, Steinberg MA, Rugle L, Krishnan-Sarin S, Potenza MN. Gambling-Related Attitudes and Behaviors in Adolescents Having Received Instant (Scratch) Lottery Tickets as Gifts. J Adolesc Health in press. http://dx.doi.org/10.1016/j.jadohealth. 2012.07.013.

35. Elman I, Becerra L, Tschibelu E, Yamamoto R, George E, Borsook D. Yohimbine-induced amygdala activation in pathological gamblers: a pilot study. PLoS One. 2012; 7(2):e31118. Epub 2012/02/10. [PubMed: 22319607]

36. Joutsa J, Johansson J, Niemela S, Ollikainen A, Hirvonen MM, Piepponen P, Arponen E, Alho H, Voon V, Rinne JO, Hietala J, Kaasinen V. Mesolimbic dopamine release is linked to symptom severity in pathological gambling. NeuroImage. 2012; 60(4):1992-9. http://dx.doi.org/10.1016/ j.neuroimage.2012.02.006. Epub 2012/02/22. [PubMed: 22348881]

37 **. Clark L, Stokes PR, Wu K, Michalczuk R, Benecke A, Watson BJ, Egerton A, Piccini P, Nutt DJ, Bowden-Jones H, Lingford-Hughes AR. Striatal dopamine D2/D3 receptor binding in pathological gambling is correlated with mood-related impulsivity. NeuroImage. 2012; 63:40-6. [PubMed: 22776462] 37.** An original research manuscript demonstrating how individual differences in context-related impulsivity relate to striatal dopamine function in pathological gambling.

38. Potenza MN, Brody AL. Distinguishing D2/D3 dopaminergic contributions to addictions: Commentary on Boileau et al: The D2/3 dopamine receptor in Pathological Gambling: A PET study with [11C]-(+)-Propyl-Hexahydro-Naphtho-Oxazin and [11C]Raclopride. Addiction. in press.

39. Leeman RF, Potenza MN. Impulse control disorders in Parkinson's disease: clinical characteristics and implications. Neuropsychiatry (London). 2011; 1:133-47. [PubMed: 21709778]

40. Reuter J, Raedler T, Rose M, Hand I, Glascher J, Buchel C. Pathological gambling is linked to reduced activation of the mesolimbic reward system. Nat Neurosci. 2005; 8:147-8. [PubMed: 15643429]

41. Miedl SF, Fehr T, Meyer G, Herrmann M. Neurobiological correlates of problem gambling in a quasi-realistic blackjack scenario as revealed by fMRI. Psychiatry Res. 2010; 181:165-73. [PubMed: 20138482] 
42. Steeves TD, Miyasaki J, Zurowski M, Lang AE, Pellecchia G, van Eimeren T, Rusjan P, Houle S, Strafella AP. Increased striatal dopamine release in Parkinsonian patients with pathological gambling: a [11C] raclopride PET study. Brain. 2009; 132:1376-85. [PubMed: 19346328]

43. Potenza MN, Steinberg MA, Skudlarski P, Fulbright RK, Lacadie C, Wilber MK, Rounsaville BJ, Gore JC, Wexler BE. Gambling urges in pathological gambling. Arch Gen Psychiatry. 2003; 60:828-36. [PubMed: 12912766]

44. Balodis IM, Lacadie CM, Potenza MN. Self-reported gambling urge intensity correlates with temporal pole activation in men with pathological gambling. J Gambl Stud. 2012; 28:493-513. [PubMed: 21811809]

45. Crockford D, Goodyear B, Edwards J, Quickfall J, El-Guebaly N. Cue-induced brain activity in pathological gamblers. Biol Psychiatry. 2005; 58:787-95. [PubMed: 15993856]

46. Goudriaan AE, de Ruiter MB, van den Brink W, Oosterlaan J, Veltman DJ. Brain activation patterns associated with cue reactivity and craving in abstinent problem gamblers, heavy smokers and healthy controls: an fMRI study. Addict Biol. 2010; 15:491-503. [PubMed: 20840335]

47. Potenza MN, Leung H-C, Blumberg HP, Peterson BS, Fulbright RK, Lacadie C, Skudlarski P, Gore JC. An fMRI stroop study of ventromedial prefrontal cortical function in pathological gamblers. Am J Psychiatry. 2003; 160:1990-4. [PubMed: 14594746]

48. Tanabe J, Thompson L, Claus E, Dalwani M, Hutchison K, Banich MT. Prefrontal Cortex Activity is Reduced in Gambling and Nongambling Substance Users During Decision-Making. Hum Brain Mapp. 2007; 28:1276-86. [PubMed: 17274020]

49. Linnet J, Peterson E, Doudet DJ, Gjedde A, Moller A. Dopamine release in ventral striatum of pathological gamblers losing money. Acta Psychiatr Scand. 2010; 122:326-33. [PubMed: 20712823]

50. Linnet J, Moller A, Peterson E, Gjedde A, Doudet D. Inverse association between dopaminergic neurotransmission and Iowa Gambling Task performance in pathological gamblers and healthy controls. Scand J Psychol. 2011; 52:28-34. [PubMed: 20704689]

51 *. Balodis IM, Kober H, Worhunsky PD, Stevens MC, Pearlson GD, Potenza MN. Diminished frontostriatal activity during processing of monetary rewards and losses in pathological gambling. Biol Psychiatry. 2012; 71:749-57. [PubMed: 22336565] 51.* An original research manuscript describing the use of a monetary incentive delay task to demonstrate in pathological gambling relatively reduced activation of 1) ventral striatum during reward anticipation that links to impulsivity in a manner similar to that observed in alcohol dependence; 2) relatively reduced activation of other reward-related regions (e.g., ventromedial prefrontal cortex, insula).

52*. van Holst RJ, Veltman DJ, Buchel C, van den Brink W, Goudriaan AE. Distorted expectancy coding in problem gambling: is the addictive in the anticipation? Biol Psychiatry. 2012; 71(8): 741-8. Epub 2012/02/22. [PubMed: 22342105] 51.* An original research manuscript describing in problem gamblers relatively increased activation of the ventral striatum to high-reward cues.

53 *. Choi J-S, Shin Y-C, Jung WH, Jang JH, Kang D-H, Choi C-H, Choi SW, Lee JY, Hwang JY, Kwon JS. Altered Brain Activity during Reward Anticipation in Pathological Gambling and Obsessive-Compulsive Disorder. PLoS One. 2012; 7(9):e45938. [PubMed: 23029329] 53.* An original research manuscript describing in pathological gambling (as compared to healthy control and obsessive-compulsive subjects) during performance of a monetary incentive delay task relatively decreased activation of ventromedial prefrontal cortex and insula and other reward regions.

54 **. Miedl SF, Peters J, Buchel C. Altered Neural Reward Representations in Pathological Gamblers Revealed by Delay and Probability Discounting. Arch Gen Psychiatry. 2012; 69:177-86. [PubMed: 22310505] 54.** An original research linking tendencies to discount rewards to reward circuitry function and problem-gambling severity in pathological gambling.

55. de Ruiter MB, Veltman DJ, Goudriaan AE, Oosterlaan J, Sjoerds Z, van den Brink W. Response perseveration and ventral prefrontal sensitivity to reward and punishment in male problem gamblers and smokers. Neuropsychpharmacology. 2009; 34:1027-38.

56. Dannon PH, Kushnir T, Aizer A, Gross-Isserhof R, Kotler M, Manor D. Alternation learning in pathological gamblers: an fMRI study. Brain Imaging Behav. 2011; 5:45-51. [PubMed: 21080118] 
57. Campbell-Meiklejohn DK, Woolrich MW, Passingham RE, Rogers RD. Knowing when to stop: The brain mechanisms of chasing losses. Biol Psychiatry. 2008; 63:293-300. [PubMed: 17662257]

58. Clark L, Lawrence AJ, Astley-Jones F, Gray N. Gambling Near-Misses Enhance Motivation to Gamble and Recruit Win-Related Brain Circuitry. Neuron. 2009; 61:481-90. [PubMed: 19217383]

59. Chase HW, Clark L. Gambling Severity Predicts Midbrain Response to Near-Miss Outcomes. J Neurosci. 2010; 30:6180-7. [PubMed: 20445043]

60. Habib R, Dixon MR. Neurobehavioral evidence for the "near-miss" effect in pathological gamblers. J Exp Anal Behav. 2010; 93:313-228. [PubMed: 21119848]

61. Rao H, Mamikonyan E, Detre JA, Siderowf AD, Stern MB, Potenza MN, Weintraub D. Decreased Ventral Striatal Activity with Impulse Control Disorders in Parkinson's Disease. Mov Disord. 2010; 25:1660-9. [PubMed: 20589879] 


\section{Highlights}

1. Noradrenergic, serotonergic, dopaminergic and other systems may influence gambling.

2. Ventral prefrontal cortical and ventral striatal systems relate to gambling.

3. Translating biological understandings of gambling to interventions is important. 
Levels of Problem-Gambling Severity

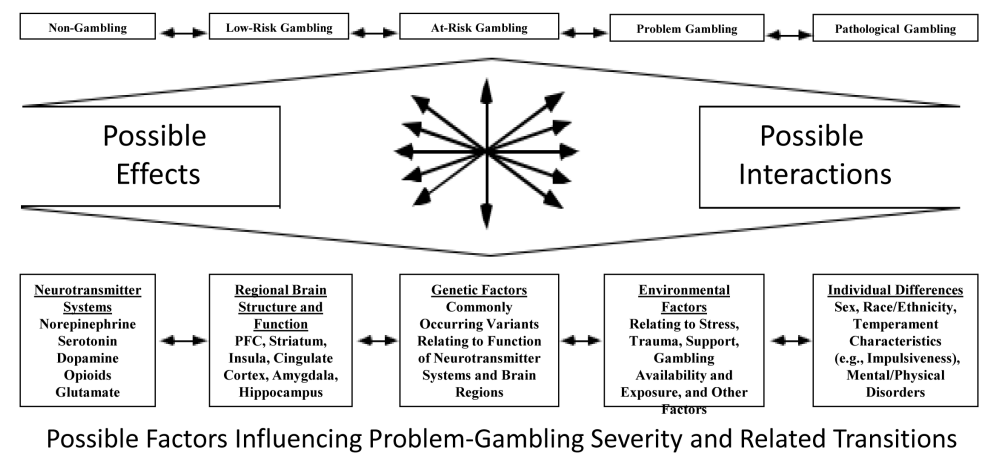

Figure 1. Proposed Levels of Problem-Gambling Severity and Possible Factors Contributing to Problem-Gambling Severity and Gambling-Related Transitions

Schematically diagrammed are different stages of problem-gambling severity ranging from non-gambling to pathological gambling. Many factors likely influence decisions not to gamble as well as the nature and extent of gambling, including participation in specific levels of gambling falling along a spectrum of problem-gambling severity (pictured on top). Domains of factors with specific examples of factors within each domain are provided (pictured on bottom). Domains may operate in main or interactive manners (indicated by a main bidirectional arrow that contains within it multiple bi-directional arrows), and may do so in ways that vary across development. Domains may influence any of the identified severity levels or stages, as schematized with the multiple bi-directional arrows. 
Table 1

Roles for Neurochemicals/Neurotransmitters in Gambling and PG

\begin{tabular}{|c|c|c|c|}
\hline $\begin{array}{l}\text { Neurochemicals/ } \\
\text { Neurotransmitters }\end{array}$ & $\begin{array}{l}\text { Study } \\
\text { Modality }\end{array}$ & $\begin{array}{l}\text { Hypothesized } \\
\text { Role }\end{array}$ & Main Findings \\
\hline Norepinephrine & $\begin{array}{l}\text { CSF, Blood, } \\
\text { Urine, Drug, } \\
\text { fMRI }\end{array}$ & $\begin{array}{l}\text { Arousal, } \\
\text { Excitement }\end{array}$ & $\begin{array}{l}\text { Elevated levels of norepinephrine and metabolites in PG } \\
\text { versus non-PG men (reviewed in [9**]); fMRI suggests } \\
\text { differential amygdalar activation to yohimbine (an alpha-2 } \\
\text { adrenergic antagonist) in PG and non-PG subjects [35] }\end{array}$ \\
\hline Serotonin & $\begin{array}{l}\text { CSF, Blood, } \\
\text { Drug, RCT, } \\
\text { PET }\end{array}$ & $\begin{array}{l}\text { Behavioral } \\
\text { Initiation } \\
\text { and Behavioral } \\
\text { Cessation (Impulse } \\
\text { Control) }\end{array}$ & $\begin{array}{l}\text { Diminished CSF levels of serotonin metabolite 5-hydroxyindole- } \\
\text { acetic acid in PG; different behavioral and } \\
\text { biochemical responses in PG and non-PG subjects to } \\
\text { metachlorophenylpiperazine } \\
\text { (m-CPP), a serotonergic partial } \\
\text { agonist at 5HT1 and 5HT2 receptors; mixed responses to } \\
\text { serotonergic drugs (serotonin reuptake inhibitors) in PG; } \\
\text { 5HT1B receptor binding in ventral striatum/putamen and } \\
\text { anterior cingulated linked to problem-gambling severity in } \\
\text { PG (reviewed in [ } 9^{* *]} \text { ) }\end{array}$ \\
\hline Dopamine & $\begin{array}{l}\text { CSF, Blood, } \\
\text { Urine, Drug, } \\
\text { PET }\end{array}$ & $\begin{array}{l}\text { Reward } \\
\text { Processing, } \\
\text { Reward-Based } \\
\text { Learning, } \\
\text { Reinforcement }\end{array}$ & $\begin{array}{l}\text { Elevated levels of dopamine metabolites observed in PG } \\
\text { versus non-PG samples; dopamine increases observed } \\
\text { during gambling; D2-like dopamine antagonists linked to } \\
\text { increased gambling motivations in PG; D2-like dopamine } \\
\text { agonists associated with PG and other ICDs in PD; Ventral } \\
\text { striatal differences in D2-like receptor binding observed in } \\
\text { PD with PG versus PD without PG but not in non-PD } \\
\text { populations; in PD, dopamine agonist treatment linked to } \\
\text { differential brain function in PG and non-PG groups during } \\
\text { card-game tasks; D2-like receptor binding linked to problemgambling } \\
\text { severity and positive urgency in PG and } \\
\text { differentially to decision-making in PG and non-PG } \\
\text { populations ([36, 37**, 38]; reviewed in [9**, 39]) }\end{array}$ \\
\hline Opioid & $\mathrm{RCT}$ & Pleasure, Urges & $\begin{array}{l}\text { Clinical trials indicate opioid antagonists (naltrexone and } \\
\text { nalmefene) superior to placebo in the treatment of PG, and } \\
\text { particularly helpful for individuals with strong gambling urges } \\
\text { at treatment onset and those with a familial history of } \\
\text { alcoholism (reviewed in }\left[9^{* *}\right] \text { ) }\end{array}$ \\
\hline Cortisol & Blood & Stress & $\begin{array}{l}\text { Elevated cortisol during gambling in PG and non-PG } \\
\text { subjects (reviewed in }\left[9^{* *}\right] \text { ) }\end{array}$ \\
\hline Glutamate & $\mathrm{RCT}$ & $\begin{array}{l}\text { Compulsiveness, } \\
\text { Cognitive } \\
\text { Inflexibility }\end{array}$ & $\begin{array}{l}\text { Preliminary data suggest that glutamatergic drugs (RCT of } \\
\mathrm{n} \text {-acetyl cysteine) superior to placebo in the treatment of } \\
\mathrm{PG} \text {, and that treatment with a glutamatergic drug (openlabel } \\
\text { memantine) may improve cognitive function/flexibility } \\
\text { (reviewed in }\left[9^{* *}\right] \text { ) }\end{array}$ \\
\hline
\end{tabular}

Abbreviations: CSF = cerebrospinal fluid; D2-like = D2 family of dopamine receptors (D2, D3 and D4); fMRI = functional magnetic resonance imaging; RCT = randomized clinical trial $; \mathrm{PET}=$ positron emission tomography; $\mathrm{PG}=$ pathological gambling; $\mathrm{RCT}=$ randomized clinical trial 
Table 2

\section{Cognitive and Neural Underpinnings of Gambling and PG}

\begin{tabular}{|c|c|c|c|}
\hline Cognitive Process & Measures & Groups & Main Findings \\
\hline Simulated Gambling & fMRI, PET & $\begin{array}{l}\text { PG, non-PG; PD } \\
\text { with PG, PD } \\
\text { without PG }\end{array}$ & $\begin{array}{l}\text { PG versus non-PG subjects show diminished vmPFC and striatal } \\
\text { activation during simulated gambling, with degree of activation } \\
\text { correlating inversely with problem-gambling severity [40]; differential } \\
\text { patterns of thalamic, IFG and temporal gyral activations in PG versus } \\
\text { non-PG [41]; in PD subjects with PG versus PD subjects without PD, } \\
\text { greater baseline availability of D2-like dopamine receptors in ventral } \\
\text { striatum and greater displacement during simulated gambling/ } \\
\text { decisionmaking } \\
\text { task [42] }\end{array}$ \\
\hline Cue Exposure & fMRI & $\begin{array}{l}\text { PG, problem } \\
\text { gamblers, non- } \\
\text { PG }\end{array}$ & $\begin{array}{l}\text { PG versus non-PG subjects show relatively diminished activation of } \\
\text { vmPFC, ventral striatum, cingulate, insula, IFG and other regions during } \\
\text { gambling cue exposure [5, 43]; self-reported gambling urges correlate } \\
\text { with activations in the temporal pole in PG [44]; increased cortical and } \\
\text { subcortical responses to gambling cue exposure in PG [45] and } \\
\text { increased activation of cortical (visual processing) and subcortical } \\
\text { (amygdala, parahippocampus) regions in problem-gambling subjects } \\
\text { [46] }\end{array}$ \\
\hline Cognitive Control & fMRI & PG, non-PG PG & $\begin{array}{l}\text { versus non-PG subjects show relatively diminished activation of } \\
\text { vmPFC [47]; activation of vmPFC, ventral striatum, and other regions } \\
\text { correlate with treatment outcome in PG [29*] }\end{array}$ \\
\hline Decision-making & fMRI, PET & $\begin{array}{l}\text { Problem- } \\
\text { gambling/SUD, SUD, } \\
\text { non- } \\
\text { problemgambling/ } \\
\text { SUD; } \\
\text { PG, non-PG }\end{array}$ & $\begin{array}{l}\text { Diminished vmPFC and other cortical activation in problem- } \\
\text { gambling/SUD group compared to non-problem-gambling/SUD group } \\
\text { [48]; striatal dopamine release during decision-making in PG associated } \\
\text { with excitement in PG [49]; different relationships between striatal } \\
\text { dopamine release and decision-making in PG and non-PG subjects } \\
\text { [50]; see also "simulated gambling" above }\end{array}$ \\
\hline $\begin{array}{l}\text { Reward/Loss } \\
\text { Processing }\end{array}$ & fMRI & $\begin{array}{l}\text { PG, non-PG, } \\
\text { OCD }\end{array}$ & $\begin{array}{l}\text { PG versus non-PG subjects show relatively diminished activation of } \\
\text { ventral striatum, insula, vmPFC and other regions [51*]; problem } \\
\text { gamblers showed relatively greater (compared to non-PG subjects) } \\
\text { activation of ventral striatum to high-value versus low-value reward } \\
\text { [52*]; relatively diminished striatal activation in PG versus non-PG and } \\
\text { OCD subjects [53*] }\end{array}$ \\
\hline $\begin{array}{l}\text { Delay and Probability } \\
\text { Discounting }\end{array}$ & fMRI & PG, non-PG PG & $\begin{array}{l}\text { versus non-PG show differences in discounting that relate to neural } \\
\text { activations in "reward" regions (vmPFC, ventral striatum, and others) } \\
\text { and problem-gambling severity [54**] }\end{array}$ \\
\hline Reversal Learning & fMRI & $\begin{array}{l}\text { Problem- } \\
\text { gambling, non- } \\
\text { PG }\end{array}$ & $\begin{array}{l}\text { Problem-gambling versus non-PG subjects showed increased response } \\
\text { perseveration and reduced activation of right ventrolateral prefrontal } \\
\text { cortex [55] }\end{array}$ \\
\hline Alternation Learning & fMRI & PG, non-PG & $\begin{array}{l}\text { In PG, problem-gambling severity correlates with cortical (prefrontal and } \\
\text { orbitofrontal) activations during alternation learning [56] }\end{array}$ \\
\hline Loss-Chasing & fMRI & Non-PG & $\begin{array}{l}\text { Decisions to chase losses versus decisions to quit associated with } \\
\text { greater activation of dorsal anterior cingulate and less activation of } \\
\text { vmPFC [57] }\end{array}$ \\
\hline Near-Miss & fMRI & PG, Non-PG & $\begin{array}{l}\text { In non-PG, near-miss events recruited "win" circuitry (insula, ventral } \\
\text { striatum) and rostral anterior cingulate activation varied with a measure } \\
\text { of control [58]; problem-gambling severity related to midbrain responses } \\
\text { to near-misses [59]; PG as compared to non-PG subjects showed } \\
\text { differences in midbrain activation and activation patterns similar to wins } \\
\text { [60] }\end{array}$ \\
\hline Risk-taking & fMRI & $\begin{array}{l}\text { PG and other } \\
\text { ICDs in PD, PD }\end{array}$ & $\begin{array}{l}\text { PD subjects with ICDs as compared to PD subjects without ICDs } \\
\text { showed perfusion of the ventral striatum and less activation of the } \\
\text { ventral striatum during risk-taking [61] }\end{array}$ \\
\hline
\end{tabular}

Abbreviations: D2-like = D2 family of dopamine receptors (D2, D3 and D4); fMRI= functional magnetic resonance imaging; ICDs = impulse control disorder; IFG = inferior frontal gyrus; PET = positron emission tomography; PD = Parkinson's disease; PG = pathological gambling; SUDs $=$ substance-use disorders; $\mathrm{vmPFC}=$ ventromedial prefrontal cortex 